\begin{tabular}{|c|c|c|}
\hline & $\begin{array}{c}\text { International Journal of Current Research in } \\
\text { Biosciences and Plant Biology } \\
\text { BXCELLENT } \\
\text { PUBLISHERS }\end{array}$ \\
Volume $4 \bullet$ Number 5 (May-2017) $・$ ISSN: 2349-8080 (Online) \\
Journal homepage: www.ijcrbp.com
\end{tabular}

\title{
Mapping and Early Transplantations of Threatened Lobaria Species in Conservation Center, Cibodas Botanical Garden
}

\author{
Lilis Supratman, Lisdar Idwan Sudirman* and Okky Setyawati Dharmaputra
}

Department of Biology, Bogor Agricultural University, Darmaga Campus, Bogor 16680, Indonesia

*Corresponding author.

\section{Abstract}

The objective of this research was to investigate the population of Lobaria in Cibodas Botanical Garden, Indonesia.The mapping of Lobaria was conductedon 3724 trees through exploration method and the samples were collected from whole tree trunk surface area with the height of 0-2 m. The transplantations used 20 thalli of $1 \mathrm{~cm} \mathrm{x} 1 \mathrm{~cm}$ with 10 thalli for each species. Only two species of Lobaria were found i.e., Lobaria retigera and L.pulmonaria with 16 total thalli and $0.14 \%$ of frequency (5 of 3724 trees). The thallus number and frequency of $L$. retigera were higher (11 thalli; $0.11 \%$ ) than L. pulmonaria (5 thalli; $0.03 \%)$ but smaller total coverage $\left(79.74 \mathrm{~cm}^{2}\right.$ per $\mathrm{m}^{2}$ of tree trunk surface area) than L. pulmonaria $\left(117.67 \mathrm{~cm}^{2}\right.$ per $\mathrm{m}^{2}$ of tree trunk surface area). Only 11 thalli of transplants (55\%) were established succesfully and growth with 4 thalli $(20 \%)$ of L. retigera and 7 thalli $(35 \%)$ of L. pulmonaria. Lobaria transplantation was succesfully. Increasing of lobule coverage in L. pulmonaria was $445.89 \%$ over 12 months transplantation, but $L$. retigera was only $33.93 \%$. Increasing of thallus coverage in $L$. pulmonaria was $104.03 \%$ during 12 months transplantation, but L. retigera was only $0.81 \%$.

\section{Introduction}

Researches lichens in Indonesia are still limited. Based on visual observations in Cibodas Botanical Garden (CBG) from 2001 to 2011 bySudirman (unpublished) found that the occurence of Lobaria was very critical.Even Lobaria specimens were not found in Herbarium Bogoriense, Indonesian Institute of Sciences (LIPI). Due to this condition themapping, identification and transplantationof Lobaria was suggested to investigate in detail.

Cibodas Botanical Garden (CBG) was chosen for sampling site because many foliose lichens were found

\section{Article Info}

Accepted: 28 August 2016

Available Online: 06 May 2017

\section{Keywords}

Cibodas Botanical Garden

Lobaria pulmonaria

Lobaria retigera

Population

Transplantation 
Lobaria is protected (van Haluwyn, 1993). Based on this information, Lobaria as rare lichens and as bioindicator environment, it must be conserved with vegetative propagated through transplantation.

Thallus (Garty and Weissman, 2001; Kon et al., 2010; Fadila et al., 2012), soredia (Werth, 2005; Kon and Yoshihito, 2010) and fragmen or thallus containing soredia can be used for transplantation. Soredia in the form of flour and mixture with water can be used transplantation and it was distributed easily. During lichen transplantation, there are several factors that must be considered for succesful transplantation, they are kind of substrate, climate, abiotic factors (temperature, humidity, light intensity, wind direction and speed, precipitation, etc.) (Armstrong and Bradwell, 2000), techniques of transplantation, and control of transplant (Coppins and Coppins, 2005).

This research project were conducted from June 2013 until June 2014 with the aims to map, to identify and to transplant of Lobaria. The purpose of mapping lichens were to get informationthe population and divercity of Lobaria at CBG. The purpose of the transplantation is to determine whether Lobaria could be reproduced at the same place and conditions.

\section{Materials and methods}

\section{Study period and location}

Mapping and transplantation of lichens were carried out from June 2013 up to June 2014 in CBG. Macroscopic and microscopic observations were performed at Common Laboratory, Department of Biology, Faculty of Mathematics and Natural Sciences, Bogor Agricultural Univercity (IPB). The preparation for permanent slides using paraffin method was performed at Laboratory of Morphology, Anatomy and Cytology, LIPI, Cibinong.

\section{Mapping Lobaria}

CBG has an area of \pm 125 ha and consists of 22 blocks. Lobaria mapping was performed at all the blocks consisting of 3724 trees using exploration method. Lobaria spp. were obtained from the whole tree trunk surface of $0-2 \mathrm{~m}$ height, they were then prepared for herbarium collection.

\section{Identification of Lobaria}

Identification of Lobaria was conducted until species level using identification keys by Ren et al. (2012). Identification of lichens consisted of macroscopic and microscopic observations and chemical reaction test. Observation of macroscopic morphology included were thallus colour, thallus surface structure, vegetative and reproductive organ structures. Microscopic characters were observed including photobiont and medulla color. Chemicals $10 \%$ potassium hydroxide $(\mathrm{KOH})$, Nahypochlorite $5.25 \%$ and other reagents were used (Brodo et al., 2001).

\section{Data analysis}

\section{Determination surface area of tree trunk}

The surface area (SA) of tree trunk was calculatedusing the followingformula:

$$
\mathrm{SA}=2 \pi \mathrm{rh}
$$

Where,

$$
\mathrm{r}(\text { radius })=\mathrm{C} / 2 \pi
$$

$\mathrm{H}=$ height of tree

$\mathrm{C}=$ circumference of tree trunk

\section{Determination of total thallus number and thethalluscoverage}

Population of lichens consisted of total thallus number, thallus coverageand frequency of thallus. Lichens were observed on all of trees using transparant plastic $(30 \times$ $20 \mathrm{~cm}$ ). Lichen covers were obtained by drawing the whole thalli on a piece of transparent plastic sheet. To measure the coverage, each thallus that had been drawn was cut off and then weighed using analytic balance. The weight was converted into centimeter squares. The weight of thallus was converted into a transparent plastic $1 \mathrm{~cm}^{2}(0.0149 \mathrm{~g})$. The coverage of thallus was calculated using formula below :

Thallus coverage $=\frac{\text { Weight of thallus } \times \text { Surface area of plastic }\left(1 \mathrm{~cm}^{2}\right)}{\text { Weight of plastic sheet }(0.0149 \mathrm{~g})}$

\section{Frequency of Lobaria}

Frequency is the thallus number Lobaria presence on each tree. Lobaria frequency was determined using the following formulawith modifications (Dietrich and Scheidegger 1997; Rugayah et al., 2004; Smith and Smith 2007): 


$$
\text { Frequency }=\frac{\text { The number of trees overgrown by Lobaria }}{\text { Total number of trees }} \times 100 \%
$$

\section{Transplantations}

The transplantation of Lobaria was carried out using thallus containing isidium and lobule at 0-1 $\mathrm{m}$ (L. pulmonaria) and $1-2 \mathrm{~m}$ (L. retigera). The transplantations were strated by making quadrant from fine yarn, then were divided up into 10 quadrants. The tree trunk in the quadrant was spread with aquades. The ten transplants were placed in each provided quadrant, held in position by fine yarn, screwed then, and covered using paranet. Maintaining and measurement the transplants were conducted every month during the whole year.
Measurement of transplant was conducted by measuring the lobule coverage using a transparent plastic sheet attached to a lobule then traced. Lobule coverage was calculated using the formula of thallus coverage.

\section{Results}

Lobaria found consisted of $L$. pulmonaria and $L$. retigera in four blocks namely block IA, II, IK and IIIA (164 tress) from 22 observed blocks on bark of Araucaria bidwilli, Prunus cerasoidesand Yucca elephantipes (3724 trees) (Fig. 1). The characteristics of Araucaria bidwilli, Prunus cerasoidesand Yucca elephantipesbarks is woody, the surface is rough, humid, wet and having a gemma.

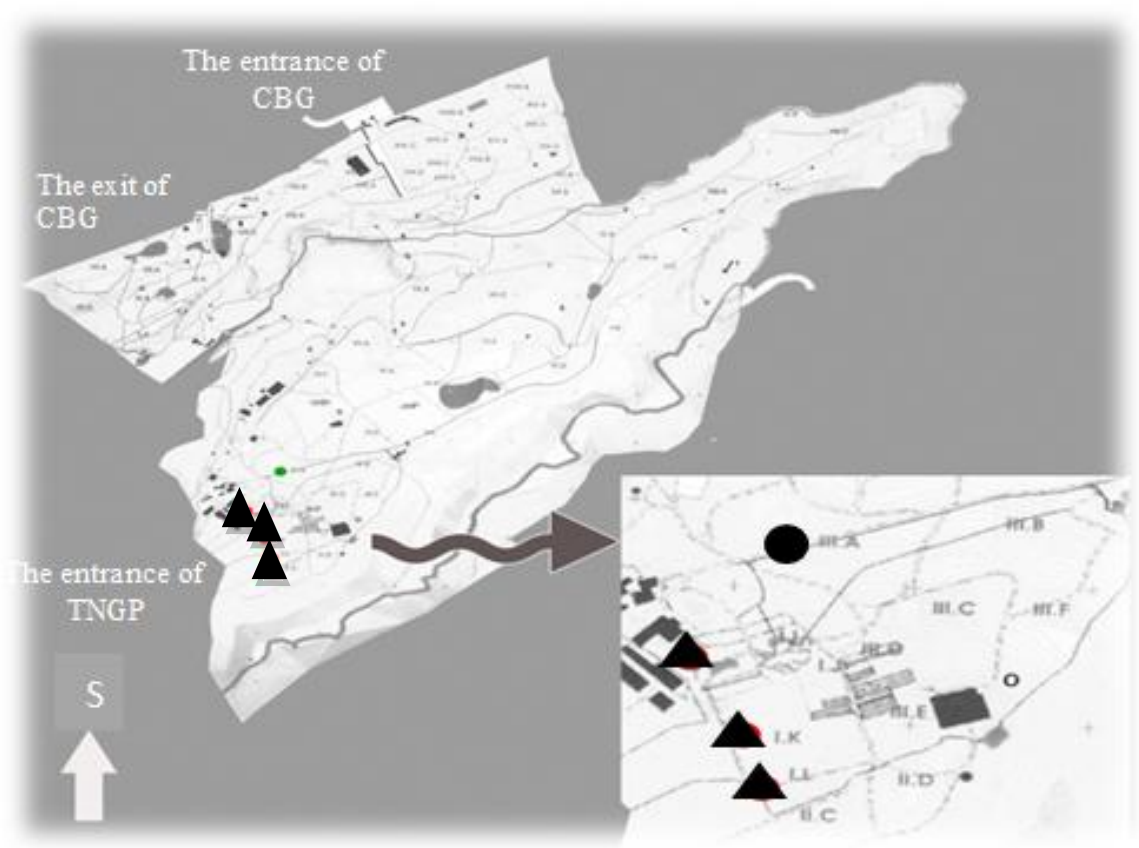

Fig. 1: Location of Lobaria retigera and L. pulmonaria in block IA, II IK and IIIA in Cibodas Botanical Garden ( $\boldsymbol{\Lambda}$ L. retigera and $\bullet$ L. pulmonaria).

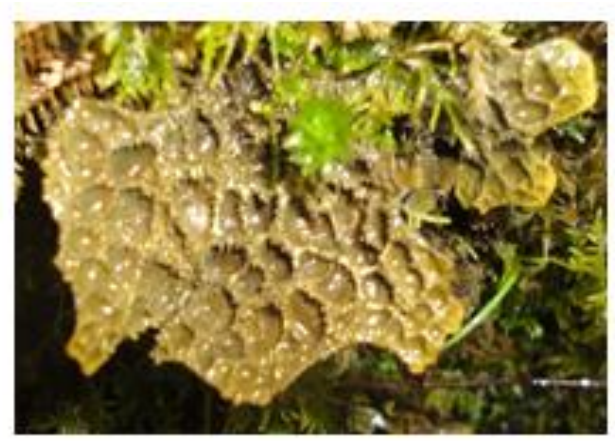

a

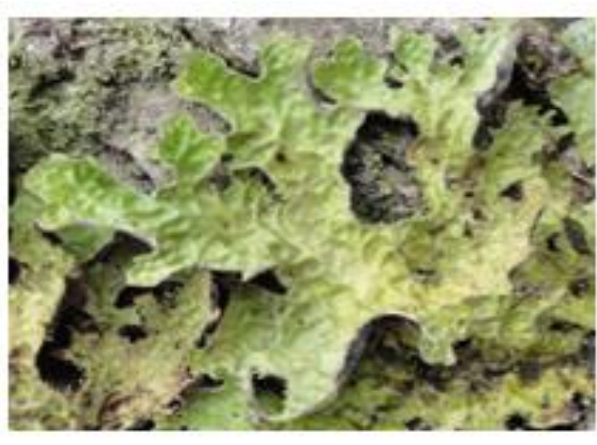

b

Fig. 2: Morphology of L. retigera (a) and L. pulmonaria (b). 
The differences between 2 Lobaria species were as follows: thallus of $L$. retigera was greenish brown, loosely attacehd to the substrate, sorediate, rhizine squarrose, black tomentum, cyanobacterial photobiont, and yellowish white medulla. Thallus of L. pulmonaria was green, firmly attached to the substrate, the soredium was not visible, unbranched rhizine, dark brown tomentum, greenalgael photobion, and white medulla.

The total number of thallus was 16 , they were 11 thallus of $L$. retigera $(68.75 \%)$ and 5 thallus of $L$. pulmonaria $(31.25 \%$ ) with total frequency $0.14 \%$ (5 trees out of 3724 tress) (Table 1). Lobaria retigera was found in three blocks, namely block IA, II and IK (109 trees) with total thallus average of $176.32 \mathrm{~cm}^{2}$ or average thallus coverage per surface area of tree trunk of 19.94 $\mathrm{cm}^{2} / \mathrm{m}^{2}$ and frequency $0.11 \%$. Lobaria pulmonaria was found in one block, namely block IIIA (55 trees) with total thallus coverage of $202.40 \mathrm{~cm}^{2}$ or average thallus coverage per surface area of tree trunkof $117.67 \mathrm{~cm}^{2} / \mathrm{m}^{2}$ and frequency $0.03 \%$ (Tables 1 and 2).

Table 1. Number of thallus and thallus coverage surface of Lobaria on each surface area on tree trunk of Araucaria bidwilli, Prunus cerasoides and Yucca elephantipes.

\begin{tabular}{llllll}
\hline Block & Trees & Lichen & $\begin{array}{l}\text { Surface area tree of } \\
\text { trunk }\left(\mathbf{m}^{\mathbf{2}}\right)\end{array}$ & $\begin{array}{l}\text { Number of thallus } \\
(\boldsymbol{\%})\end{array}$ & $\begin{array}{l}\text { Thallus } \\
\text { coverage }\left(\mathbf{c m}^{\mathbf{2}}\right)\end{array}$ \\
\hline IA & Prunus cerasoides & Lobaria retigera & $4.22 *$ & $2(12.5)$ & $23.99 * *$ \\
& P. cerasoides & L. retigera & 1.76 & $1(6.25)$ & 41.53 \\
II & P. cerasoides & L. retigera & 1.66 & $5(31.25)$ & 73.78 \\
IK & Yucca elephantipes & L. retigera & 6.16 & $3(18.75)$ & 37.02 \\
& Subtotal & & $\mathbf{1 3 . 8}$ & $\mathbf{1 1}(\mathbf{6 8 . 7 5})$ & $\mathbf{1 7 6 . 3 2}$ \\
IIIA & Araucaria bidwilli & L. pulmonaria & 1.72 & $5(31.25)$ & 202.40 \\
& Subtotal & & $\mathbf{5 ( 3 1 . 2 5 )}$ & $\mathbf{2 0 2 . 4 0}$ \\
& Total & & $\mathbf{1 5 . 5 2}$ & $\mathbf{1 6 ( 1 0 0 )}$ & $\mathbf{3 7 8 . 7 2}$ \\
\hline
\end{tabular}

Note: * Surface area of tree trunk $=2 \pi \mathrm{rt}$. Radius $(\mathrm{r})=$ circumference $/ 2 \pi$.

$* *$ Coverage surface $=[$ weight of thallus/weight of plastic $(0.0149 \mathrm{~g})] \times$ surface area of plastic sheet $\left(1 \mathrm{~cm}^{2}\right)$

Tabel 2. Frequency of Lobaria based on 3724 trees.

\begin{tabular}{llll}
\hline Block & Lichen & $\begin{array}{l}\text { The number of trees overgrown of } \\
\text { Lobaria }\end{array}$ & Frequency of Lobaria $(\%)$ \\
\hline IA & Lobaria retigera & 2 & \\
II & L. retigera & 1 & 0.11 \\
IK & L. retigera & 1 & \\
& Subtotal & $\mathbf{4}$ & 0.03 \\
IIIA & L. pulmonaria & 1 & $\mathbf{0 . 1 4}$ \\
& Subtotal & $\mathbf{1}$ & $\mathbf{5}$ \\
& Total & &
\end{tabular}

A total of 11 transplants $(55 \%)$ was able to grow, they were 4 transplants (20\%) of L. retigera and 7 transplants (35\%) of L. pulmonaria. The growth of transplants increased from January up to June 2014 (Fig. 2). Increasing of lobule coverage in L. pulmonaria was $445.89 \%\left(0.0852 \mathrm{~cm}^{2}\right.$ to $\left.0.4651 \mathrm{~cm}^{2}\right)$ during 12 months transplantation, but $L$. retigera was only $33.93 \%(0.3658$ $\mathrm{cm}^{2}$ to $0.4899 \mathrm{~cm}^{2}$ ) (Fig. 4). Increasing of thallus coverage in L. pulmonaria was $104.03 \%\left(1 \mathrm{~cm}^{2}\right.$ to $2.0403 \mathrm{~cm}^{2}$ ) during 12 months transplantation, but $L$. retigera was only $0.81 \%\left(1 \mathrm{~cm}^{2}\right.$ to $\left.1.0081 \mathrm{~cm}^{2}\right)$ (Fig. 5 ).

The growth of transplants was affected by climate. Average climate in CBG had temperature of $19.8^{\circ}-$ $19.7^{\circ} \mathrm{C}$ and humidity of $85 \%-91.1 \%$ from January 2013 up to February 2014 (Fig. 6). The transplantation was conducted in June 2013 during dry season in temperature of $11.9^{\circ}-20^{\circ} \mathrm{C}$ and humidity of $85 \%-90.9 \%$ for 6 months. At the time the the lobules and thallus did not grow rapidly. Nevertheless, they grew rapidly in January up to June 2014 (Fig. 4). However, the data of temperature and humidity on those months were not recorded. For instance the range of temperatures from January up to May of 2013 was $19.7^{\circ}-20^{\circ} \mathrm{C}$ and the range of humidity was $90.8-92.6 \%$. Therefore, the humidity was a very important factor compared to the temperature. It is suggested that transplantation should be performed in January up to May because at that time the condition is more humid so that it will be a lot of chance for the transplants to grow rapidly (Fig. 6). 


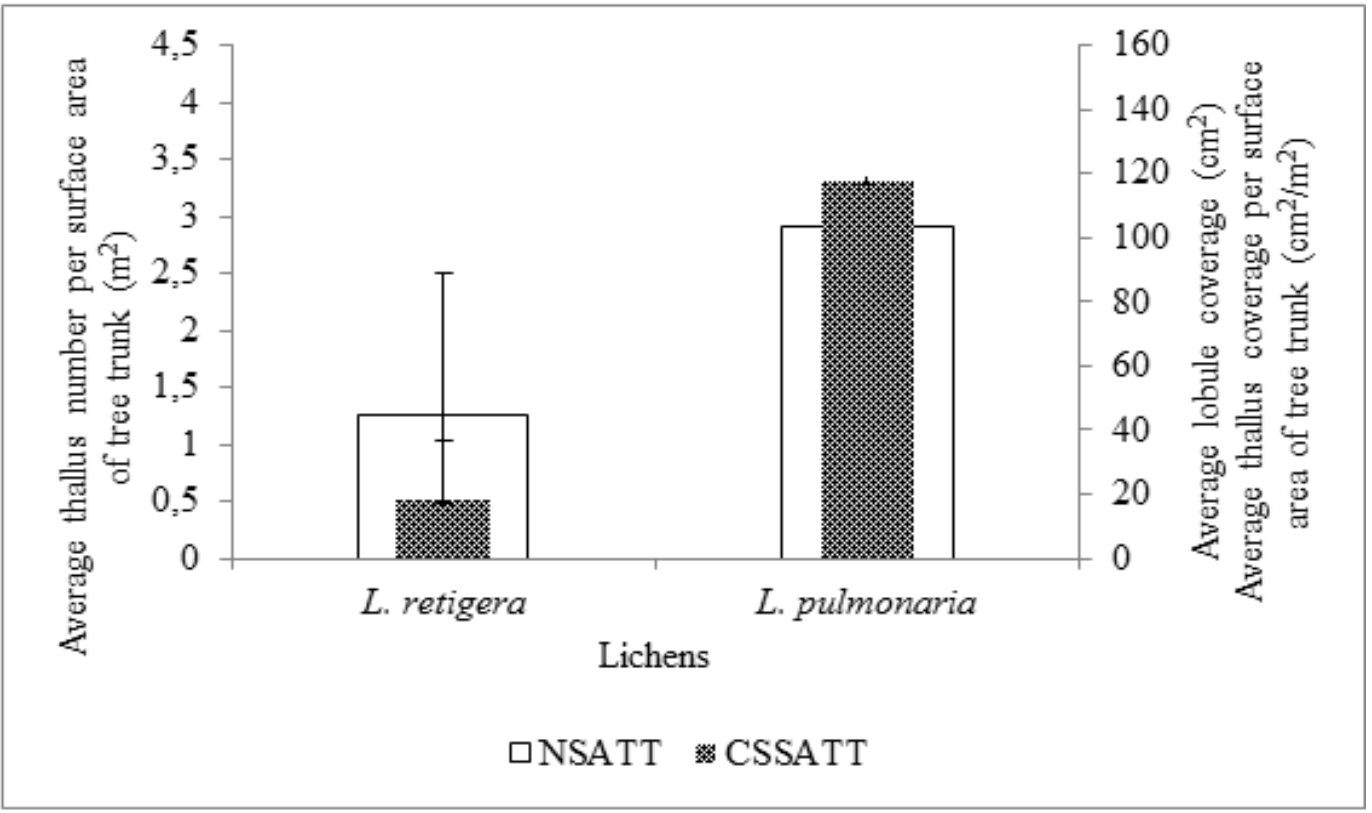

Fig. 3: Thallus number thallus and thallus coverage of tree trunk.

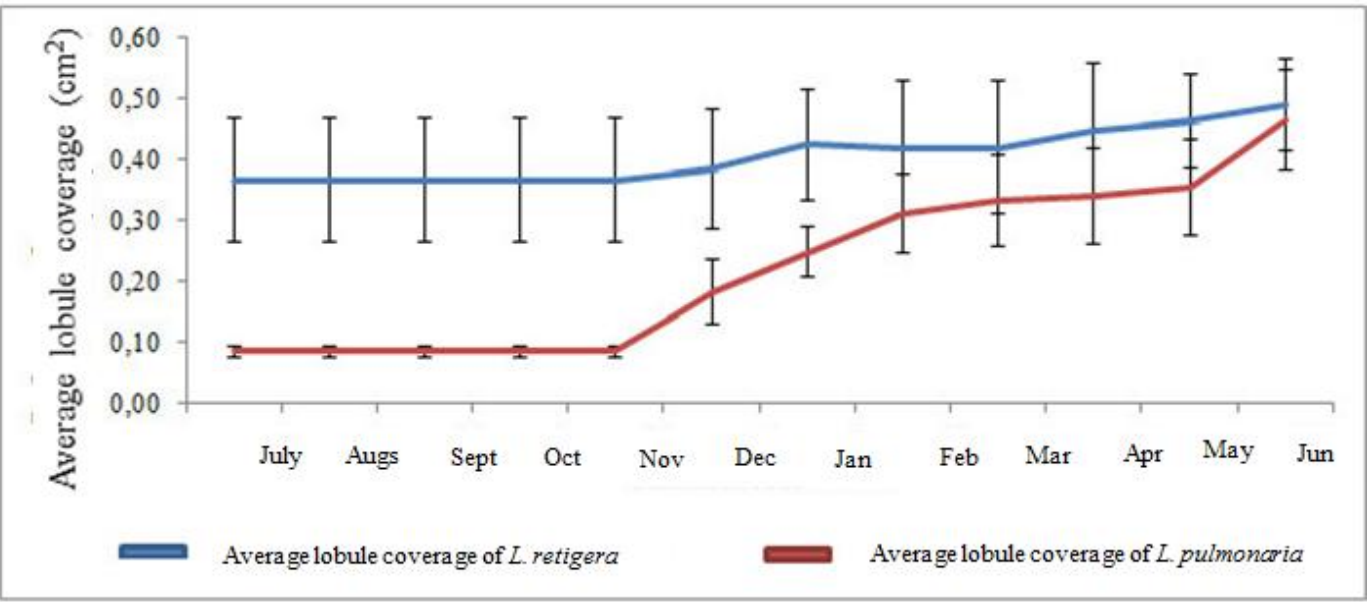

Fig. 4: Growth of lobule coverage.

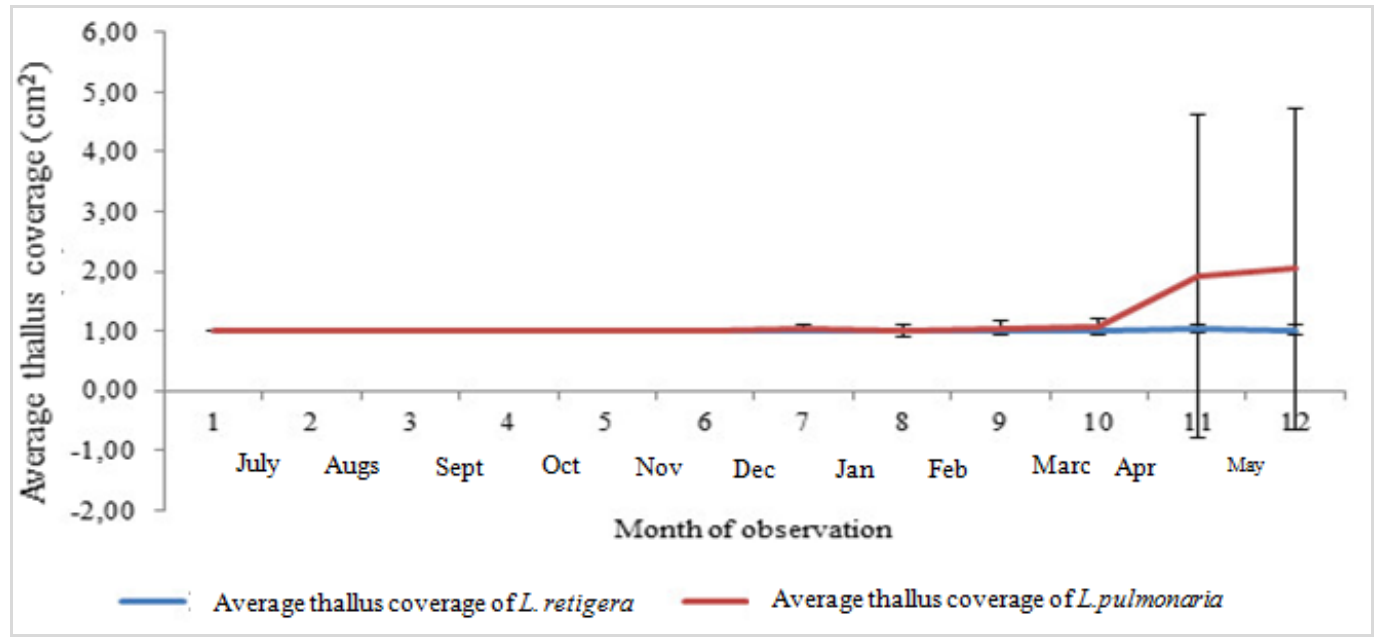

Fig. 5: Growth of thallus coverage. 


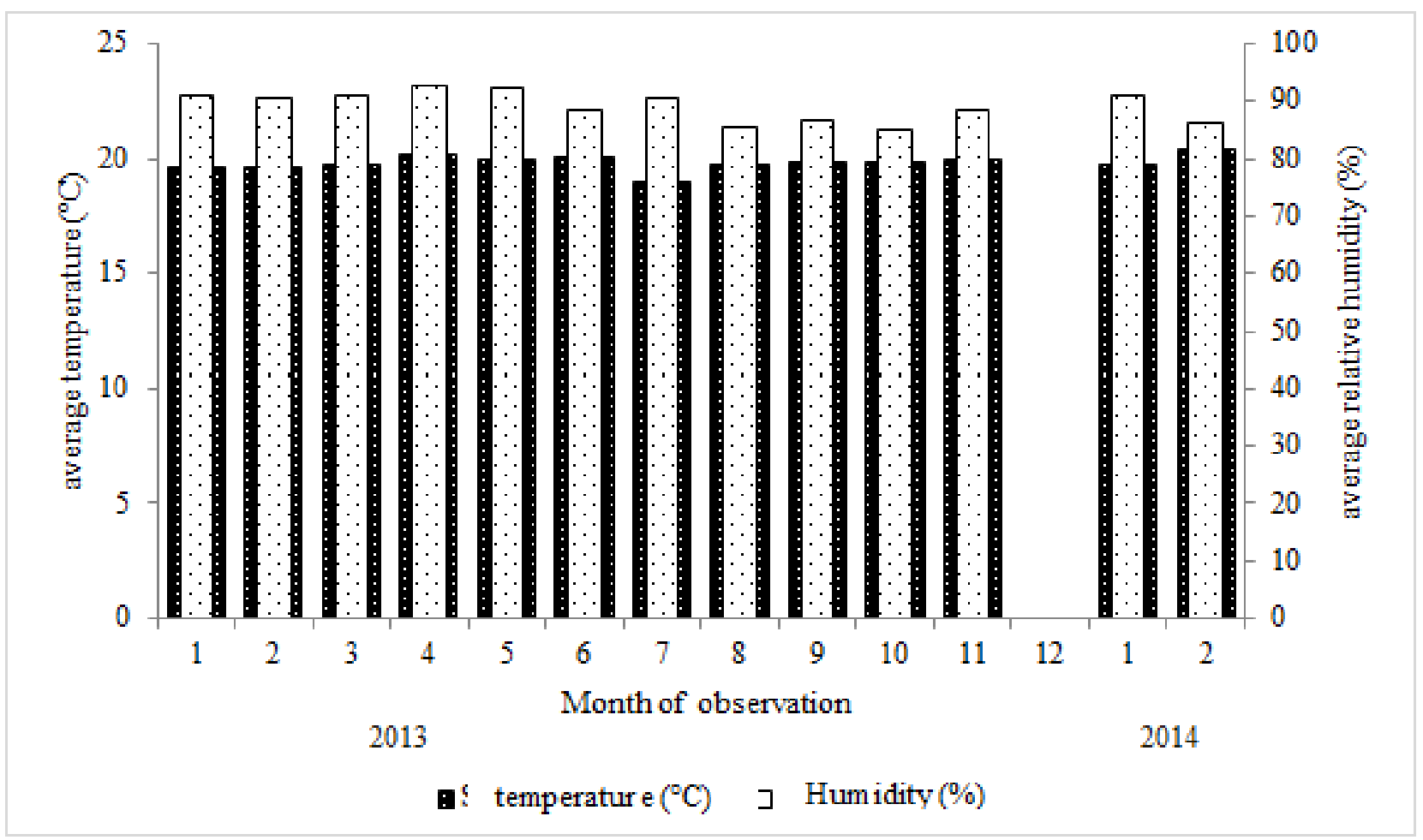

Fig. 6: Average temperature and average humidity of the months in Cibodas Botanical Garden.

\section{Discussion}

The mapping results showed that ofLobariapopulation is very critical, indicated with the fact that on out of 3724 trees L. pulmonaria was only found on one tree, i.e. Araucaria bidwili which was induced from Queensland (Australia) (Database of CBG, unpublished). In addition, L. retigera was found on Prunus cerasoides and Yucca elephantipes induced from Himalaya and Mexico (Database of CBG, unpublished). The bark characteristics of those species are allegedly suitable for Lobaria to grow. Other factors influencing $L$. pulmonaria growth, in addition to bark physicochemical characteristics, are substrate texture (Moxham 1981, Armstrong 1993) and thallus position on the substrate (Armstrong, 1987).

The bark of Prunus cerasoides, Yucca elephantipes, and Araucaria bidwili is woody, rough surfaced, moist, wet, and with gemma, indicating that Lobaria grows on the bark of various species. Every species has different ability in saving water, highly depending on trunk's porosity and texture (Hale 1983). Rough bark surface is used by thallus to firmly attach. Brodo et al. (2001) stated that every tree is capable of naturally producing chemical compound which can help lichens survival. In addition, barks characteristics and conditions influence thallus shape and growth (Brodo et al., 2001). The fact that $L$. pulmonaria and L. retigera were only found in block I and III indicated that the lichens can serve as air quality bio-indicator because the blocks were located far from vehicular traffic, in addition to having fewer visitors. This is in accordance with Purvis (2000) who stated that Lobaria is sensitive to air pollution.

Lobaria retigera are commonly found on the trunk of Prunus cerasoides. Therefore, the transplantations were carried out on the trunk of the species (as transplant natural substrate) in order to make the transplant grow and develop well. Coppins and Coppins (2005) stated that the transplantation of foliose thallus is more suitable to be carried out on trunk rather than on stone. Transplant materials used were isidiate thallus with lobule. Selecting thallus as transplant material should take into following consideration, e.g. wide lobes grows faster than the narrow one; thallus with young, intact lobes grows faster than sorediate and mature thallus.The variance in lobes growth depends on lobes properties rather than on the overall thallus (Scheidegger et al., 1995). Variance in lobes growth is due to allocation, metabolism and different carbohydrate production (Armstrong and Smith, 1994).

A total of 11 transplants were successfully transplanted 
(55\%) while the other $45 \%$ did not well grow due to several reasons, e.g. thallus dried and color changed; thallus did not well attached on the substrate; thallus size reduced; and thallus contained no young lobes. This result was in accordance with Philips (1969) where the study resulted in well grew transplants but the other lobes did not manage to grow at all. Mature thallus is capable of growing in various conditions, while isidia growth is influenced by light intensity and wind direction (Scheidegger et al., 1995).

Based on the transplant results, it is recommended that transplantation is carried out from January to May because the humidity during the period is higher, making the transplants have higher possibility to rapidly grow. Climatic condition suitable for thallus growth is the key factor for the successful transplant attachment on natural substrate. Accordingly, less favorable climatic condition hinders the degeneration process of diaspora transplanted (Scheidegger et al., 1995).

\section{Conclusion}

Two lichen species were found, i.e., Lobaria retigera and Lobaria pulmonaria. Lobaria grows on bark of Araucaria bidwilli, Prunus cerasoides and Yucca elephantipes. Lobaria population is very critical. Transplantations were established succesfully. The growing transplant result of $L$. pulmonaria was higher than $L$. retigera.

\section{Conflict of interest statement}

Authors declare that they have no conflict of interest.

\section{Acknowledgement}

Authors thank Jae-Seoun for confirming the Lobaria specimen identification and Cibodas Botanical Garden for providing the data.

\section{References}

Armstrong, R.A., Bradwell, T., 2000. Growth of Foliose Lichens. British Geological Survey, Edinburgh, United Kingdom. Birmingham, Aston University.

Armstrong, R.A., Smith, S.N., 1994. The levels of ribitol, arabitol and annitol in individual lobes of the lichen Parmelia conspersa (Ehrh. ex Ach.) Ach. Env. Exp. Bot. 34(1), 253-260.

Armstrong, R.A., 1987. Dispersal in a population of the lichen Hypogymnia physodes. Env. Exp. Bot. 27(1), 357-363.

Armstrong, R.A.,1993c, The growth of six saxicolous lichens transplanted to lime-rich and lime-poor substrates in South Gwynedd, Wales. Symbiosis. 15(1), 257-267.

Brodo, I.M., 1973. Substrate ecology. In: The Lichens (Eds.: Ahmadjian, V., Hale, M.E.). Academic Press, London and New York.

Brodo, I.M., Sharnoff, S.D., Sharnoff, S., 2001. Lichens of North America. Connecticut (US), Yale University Press.

Coppins, A.M., Coppins, B.J., 2005. Monitoring of experimental lichens transplans of Catapyrenium psoromoides. Commissioned Report No. 085 (ROAME No. F03LH14). Edinburgh (BG), Scottish Natural Heritage.

Dietrich, M., Scheidegger, C., 1997. Frequency, diversity and ecological strategies of epiphytic lichens in the Swiss Central Plateau and the PreAlps. Lichenologist. 29(3), 237-258.

Ellis, C.J., Coppins, B.J., 2007. Changing climate and historic woodland structure interact to control species diversity of the 'Lobarion' epiphyte community in Scotland. J.Veget. Sci.18(5), 725-734.

Fadila, K., Berrebbah, H., Djebar, M. R., 2012. Study of atmospheric pollution emitted rated a plant of fertilizers (Algeria) by the use of bioindicator plants: lichens. Adv. Environ. Biol. 6(5), 1823-1833.

Garty, J., Weissman, L., 2001. Transplanted lichens in and around the Mount Carmel National'Park and the Haifa Bay Industrial Region in Israel: Physiological and chemical responses. Environ. Resc. Sect. 85, 159-176.

Hale, M.E., 1973. Growth. In: The lichens (Eds.: Ahmadjian, V., Hale, M. E.). Academic Press, New York. pp.473-492.

Hale, M. E., 1983. The Biology of Lichenss. San Fransisco (US), Edward Arnold.

Kon, Y., Yoshihito, O., 2010. Regeneration of juvenile thalli from transplanted soredia of Parmotrema clavuliferum and Ramalina yasuda. Bull. Natl. Mus. Nat. Sci. 36, 65-70.

Moxham, T. H., 1981. Growth rates of Xanthoria parietina and their relationship to substrate texture. Cryp. Bryol. Lichenol. 2(1), 171-180.

Phillips, H.C., 1969. Annual growth rates of three species of foliose lichens determined photographically. Bull. Torr. Bot. Club. 96, 202-206.

Purvis, W., 2000. Lichens. Smithsonian Inst Pr., Washington DC (US). 
Ren, M.R., Wang, Xin Y.W., Koh, Y.J., Jae, S.H., 2012. Taxonomic study of the lichens genus Lobaria in South Korea, Mycobiology. 40(1), 1-7.

Rugayah, Widjaja, E.A., Praptiwi, 2004, Pedoman Pengumpulan Data Keanekaragaman Flora, Bogor (ID), Pusat Penelitian Biologi-LIPI.

Scheidegger, C., Frey, B., Zoller, S., 1995. Transplantation of symbiotic propagules and thallus frgaments: Methods for the conservation of threatened epiphytic lichen populations. Forsch. Anst. Wald. Schnee. Landsch. 70(1), 41-62.

Sharnoff, S.D., 2002. Lichens, Biology and Environment the Special Biology of Lichens. Win.
C. Company, Connecticut (US).

Smith, R.L., Smith, T.M., 2007. Elements of Ecology. Benjamin Cummings, San Fransisco (US).

Van Haluwyn, C., 1993. Guide des Lichens. Lechevalier, Paris(FR).

Walser, J.C., Zoller, S., Büchler, U., Sheidegger, C., 2002. Species-specific detection of Lobaria pulmonaria (lichensized Ascomycete) diaspores in litter samples trapped in snow. Mol. Ecol. 10, 21292138.

Werth, S., 2005. Dispersal and Persistence of an Epiphytic Lichen in a Dynamic Pasture-woodland Landscape [Thesis], Universität Bern.

\section{How to cite this article:}

Supratman, L., Sudirman, L. I., Dharmaputra, O. S., 2016. Mapping and early transplantations of threatened Lobaria species in Conservation Center, Cibodas Botanical Garden. Int. J. Curr. Res. Biosci. Plant Biol. 4(5), 1-8. doi: https://doi.org/10.20546/ijcrbp.2017.405.001 